Катарина Милосављевић*

Пољопривредни факултет Крушевац

Универзитет у Нишу
371.3::811.134.2'243

https://doi.org/10.18485

/zivjez.2020.40.1.11

Стручни рад

\title{
ДВА НАЧИНА СПРОВОЪЕЊА ЈЕЗИЧКЕ ОБРАЗОВНЕ ПОЛИТИКЕ: ОДОЗГО-НА-ДОЛЕ И ОДОЗДО-НА-ГОРЕ; ПРИКАЗ ЈЕДНЕ СТУДИЈЕ СЛУЧАЈА
}

Циљ овог рада је да, кроз детаљан преглед литературе, пружи увид у концепте језичке политике и планирања као и језичке образовне политике, јер се управо језичка образовна политика бави језицима у формалним образовним системима. Будући да енглески језик заузима значајно место у универзитетској настави и да је већина литературе као и публикација са SCI (Science Citation Index) листе на енглеском, познавање тог страног језика се сматра битном квалификацијом коју академски грађани треба да поседују, јер им пружа могућност да се укључе у међународне токове. Из тог разлога, у раду је приказана студија случаја спровођења језичке образовне политике на Пољопривредном факултету у Крушевцу Универзитета у Нишу. Битно је нагласити да циљ рада није да прикаже који начин спровођења језичких образовних политика је бољи, већ да пружи увид у начине њиховог функционисања.

Кључне речи: језичка образовна политика, језичка политика и планирање, настава страних језика, енглески језик, високо образовање.

\section{1. Увод}

Језици у образовном систему и њихова усклађеност и значај једна су од важних тема дискусија и акција у образовним системима света. Улагања у наставу језика, а посебно страних језика, којим руководе владе или образовне институције, као и бројне организације приватног сектора, захтевају

* milosavljevic.katarina@ni.ac.rs 
систематску анализу који су то језици чије ће учење донети највеће предности појединцима, друштву у најширем смислу и економији земље. Неки језици преузимају доминантан положај у односу на друге помоћу афирмације снаге и моћи својих говорника. Ако је некада та моћ била изражена војном снагом, у наредним фазама моћ језика преносила се војном надмоћи, да би се у данашње време, сасвим јасно препознала у економској доминацији. Такав је случај и са доминантним језиком доба у коме живимо. Језик који најчешће служи за споразумевање у савременом свету је без сваке сумње енглески (Вучо 2018: 35).

Момчиловић (2012: 617) истиче да је језичка политика у Европи последње две деценије у врењу, као и да постоје различита мишљења по питању улоге и употребе енглеског језика и остваривости вишејезичности, објашњавајући да се ти различити ставови огледају кроз призму језичког империјализма, лингвистичке екологије, контактне лингвистике и других језичких концепата и теорија о ширењу језика и језичким променама.

Примећујући да ниједна дефиниција језичких образовних политика нема универзално „одобрење“, Ранко Бугарски (1992) је пружио корисну полазну тачку дефинишући језичке политике као политике друштва у сфери лингвистичке комуникације, односно као сет позиција, принципа и одлука које одражавају став тог друштва према свом вербалном репертоару и комуникативном потенцијалу. Из тога можемо закључити да су језичке образовне политике одраз идеолошких виђења и оријентација једног друштва, владе, институција или појединаца. У прилог томе иде тврдња Сполског (2004) да је језичка идеологија у ствари језичка политика из које је изостављен менаџер и оно што људи мисле да треба бити урађено са језиком.

Многи аутори су установили да у последње време долази до све већег броја сличних образовних реформи са заједничким сетом одлука широм света, па чак и у оним деловима чије се културе и нивои економског развоја увелико разликују. Вергер (2012: 5) тај феномен заједничких обележја образовних реформи назива глобална образовна политика и дефинише 
је као све популарније подручје истраживања унутар којег се „испитују различити начини на које процеси глобализације, актери и догађаји доприносе промени образовне политике и са којим последицама“. Према бројним ауторима, појава глобалне образовне политике је обележила крај 20. и почетак 21. века, а срж те појаве почива на механизмима попут дифузије или конвергенције образовних политика. Они такође сугеришу како је све образовне трендове потребно посматрати кроз призму односа државе и образовања у глобалном окружењу, због чега је, пре дефинисања тих трендова, потребно увидети како је до њих уопште дошло. Многи аутори су се бавили дефинисањем појма глобализације, али бих посебно издвојила Хелда (2001: 67) који на основу података из различитих извора глобализацију дефинише као процес трансформације друштвених односа у којима се рађају трансконтиненталне и међурегионалне везе. Вергер (2012) је покушао да дефинише на које све аспекте креирања образовне политике глобализација има утицај, па је тако дошао до закључка како је глобализација преузела улогу идентификовања нових питања и проблема које „просветне власти“ треба да реше. Исти аутор сматра да глобализација мења начине на које државе путем образовне политике приступају образовним и другим проблемима од јавног интереса.

\section{2. Језичке образовне политике}

У раду Planning for a Standard Language in Modern Norway аутора Хаугена по први пут се среће термин „језичко планирање“ који он објашњава на следећи начин:

Језичко планирање разумем као активност припреме нормативне ортографије, граматике и речника који ће послужити у писању и говору особа из нехегемоних говорних заједница. Оно представља практичну апликацију лингвистичког знања и искорак из дескриптивне лингвистике у област доношења одлука у вези са одабиром језичких форми. (Хауген 1959: 8) 
Филиповић (2017) објашњава језичку политику и планирање као културну, друштвену, политичку и лингвистичку активност, додајући да она датира од самих зачетака друштвене организације и од првих покушаја интерјезичке и интеркултурне комуникације међу представницима различитих друштвених, културних, етничких, религијских и других група. Ауторка такође додаје да се у приручницима социолингвистике и примењене лингвистике језичка политика и планирање дефинише као организована, циљана и дугорочна активност институција државе у области одабира лингвистичког кода који преузима статус званичног језика у држави, затим лингвистичких форми и лексике одабраног званичног језика као и одабира језика који ће се користити као језици образовања, односно као додатни/страни/други језици у датом образовном систему (Филиповић 2017: 218).

Ако имамо на уму то да су језичка политика и планирање у директној корелацији са позицијама друштвене и политичке моћи, онда је јасно да се у нашој земљи језичка политика спроводи по принципу познатијем као „одозго-на-доле“, односно, државне институције кроз наставне планове и програме и остале материјале одређују шта је правилно и прихватљиво у корпусу одређеног језика. Филиповић у истом раду додаје:

Таква врста стандардизације веома често нема могућност адекватног реаговања и препознавања језичких промена које прате промене структура и односа унутар говорних, друштвених, културних и других заједница. И што је најзначајније, таква врста језичке политике и планирања и даље је доминантна у великом делу света, па и у нашој земљи и региону. Ригидна, нетолерантна, неспремна да уочи, прихвати и објасни разлоге за језичку промену и друштвену потребу која иза те промене стоји. (Филиповић 2017: 223)

Због свега наведеног, ауторка даље у истом раду наводи да: 
ДВА НАЧИНА СПРОВОЪЕЊА ЈЕЗИЧКЕ ОБРАЗОВНЕ ПОЛИТИКЕ...

Епистемиолошка и (стратешка) парадигма, међутим, намеће један алтернативни приступ тумачењу концепта језичке политике и планирања и базира се на конструктивистичкој, трансдисциплинарној научноистраживачкој парадигми, која преиспитује све кључне концепте како ове тако и других области људске науке и мишљења, те нуди алтернативна одређења појмова као што су језик, стандардизација, култура, наука, политика знања, итд. (Филиповић 2017: 222)

Ауторка затим нуди ново гледиште и активности језичког планирања „одоздо-на-горе“, наводећи да се то ново гледиште „удаљава од идеје да је једина валидна језичка политика политика језичке стандардизације, формирана на културном моделу модерности и на идеологији писане речи, пречишћеног и рафинираног стандарда коме приступ имају само одабрани представници културних и политичких елита“ (Филиповић 2017: 222).

Управо је овакво ново гледиште језичког планирања одоздо-на-горе довело до идеје за овај рад, чији је циљ да представи оба начина спровођења језичке политике, и одозгона-доле (енгл. top-down) и одоздо-на-горе (енгл. bottom-up), са намером да се стекне бољи увид у начине спровођења језичких политика користећи примере из праксе. Напоменула бих да циљ рада није покушај да се докаже који је од два горе наведена начина спровођења језичке политике бољи, већ има за циљ да прикаже начине како они функционишу.

\section{3. Два начина спровођења језичке образовне политике: „одозго-на-доле“ и „одоздо-на-горе“}

Како бих боље приказала разлику између спровођења два начина језичке политике представићу рад Нитфулинија (2001) који се бави проучавањем система одозго-на-доле и одоздо-на-горе али не при спровођењу језичке политике већ при усвајању страних језика, зато што верујем да прављење ове врсте паралеле може послужити као веома једноставан 
пример за разумевање та два начина спровођења језичке политике.

У раду се наводи да је на приступ одоздо-на-горе утицала бихејвиористичка психологија педесетих година, која је тврдила да се учење заснива на формирању навика изазваних поновљеним повезивањем стимулуса са одговором. То значи да ученик прави асоцијације за често виђена слова, речи, реченице, слике, догађаје и, како се ове правилности или обрасци користе изнова и изнова, кроз понављања и вежбе постају све јачи и долази до процеса усвајања. Такви ученици који науче нешто користећи приступ одоздо-на-горе могли би да примене у пракси оно што су прочитали. Супротно томе, процес усвајања одозго-на-доле ослања се на претходно знање ученика како би дошло до декодирања порука. Складиште информација, које називају шема, може се односити на контекст, тему, врсту текста, реторику и организацију дискурса. Ово знање постаје корисно за декодирање порука чак и када се порука није чула у целости (Нитфулини 2001: 2).

У раду Теоријски концепти и специфичности језичке образовне политике Филиповић објашњава да се:

[у] стандарднојезичким културама, каква је и српска, језичка политика и планирање се спроводи пре свега „од врха“ (енгл. top-down approach), односно са нивоа државних референтних институција које кроз прескриптивне приручнике, граматике и наставне планове и програме у формалном образовању диктирају који су облици прихватљиви и правилни у корпусу датог стандардног језика. Таква врста стандардизације веома често нема могућности адекватног реаговања и препознавања језичких промена које прате промене структура и односа унутар говорних, друштвених, културних и других заједница. (Филиповић 2014: 23)

Даље у наставку истог рада ауторка наводи да је свакако било покушаја да се та ситуација промени, а као доказ томе наводи пример објављеног чланка под називом Шта вири 
ДВА НАЧИНА СПРОВОЪЕЊА ЈЕЗИЧКЕ ОБРАЗОВНЕ ПОЛИТИКЕ...

врх дечерме: Осврт на збирку задатака из српског језика: Да ли видиш шта раде са твојом децом (Партибрејкерс)? у коме Савица и Ђурић (2006) критикују доминацију вуковског језика како би се на њему тестирале ученичке компетенције и познавање граматичких структура српског језика, а такође наводе да збирке фаворизују текстове писане током векова српске историје у контексту строгих патријархалних културних модела. Филиповић (2014) закључује:

Отварањем простора за деловање оваквог типа, који се може дефинисати као језичка политика „одоздо-на-горе“, односно као de facto језичка образовна политика, у српску образовну сферу уносимо једно ново и критичко тумачење онога што језик јесте, за шта се он користи и која је права природа језичких компетенција које треба развијати током формалног образовног процеса. Тек када и формално препознамо и научимо да вреднујемо процене и закључке заинтересованих професионалних делатних заједница на систематичан и структурисан начин, моћи ћемо да почнемо са дефиницијом de iure нових језичких образовних политика („с врха“), које ће у обзир узети и потребама наше говорне заједнице прилагодити образовну документацију која се тиче српског стандардног језика. (Филиповић 2014: 25)

У жељи да овај рад обогатим примерима, а не да се заснива само на теоријским објашњењима, пронашла сам рад под називом Language Initiatives from up to bottom and bottom up (Уједињене Нације 2016) који је настао као резултат састанака међународне групе експерата Уједињених Нација, сектора за економскаи друштвена питања (енгл.UNDepartmentofEconomic and Social Affairs, Division for Social Policy and Development, Secretariat of the Permanent Forum on Indigenous Issues). На почетку рада се наводи да доба глобализације није донело много позитивних резултата за одрживост бројних матерњих језика, већ је најчешће повезано са колонизацијом, болестима, пресељавањем, деструктивним језичким политикама и многим 
другим. Током последњих деценија, ова кршења људских права постала су регулисана међународним споразумима, што је значајно достигнуће данашњег друштва. Међутим, нису све државе одлучиле да следе ове прописе; историја пружа примере влада које су промениле своја гледишта и политике. Као један од примера у раду се наводе покушаји власти да у Русији ревитализују Ителмен језик, језик којим говоре људи који живе у источном делу Русије, такозвани руски Далеки Исток. Аутори овог рада су 2010. године учествовали на парламентарном саслушању државне думе на тему Language Diversity of the Russian Federation: Problems and Perspectives где je наглашено следеће: „Циљ савремене државне политике Руске Федерације лежи у јачању духовне консолидације вишенационалне Русије у јединствену грађанску нацију која одржава етно-културолошку и језичку разноликост“ (2016: 2). У наставку рада се наводи да се постојеће законодавство Руске Федерације односи на решавање питања матерњих језика углавном у сфери образовања. Ревитализација језика углавном се посматра кроз класичне формалне часове. C тога је 2014. године влада Камчатског краја усвојила „Комплекс мера о очувању и пропаганди традиционалне културе, обезбеђивању традиционалног животног окружења и традиционалном коришћењу земљишта доморадачких народа севера, Сибира и Далеког истока који живе у Камчатском крају за 2014-2018“ (2016: 4). У септембру 2015. године део овог комплекса допуњен је додатним одељком под називом „Очување и развој матерњих језика, подршка и развој штампаних и електронских средстава масовне комуникације“. У овом комплексу, Влада наглашава вредност масовних медија, академских истраживања и расправа, објављивање језичких и културних образовних материјала, организацију језичких такмичења и културних догађаја. Све ове мере могу добро да функционишу уз одговарајућу финансијску подршку, доследност и смернице. Након тога, у раду су представљени практични примери које је локална самоуправа предузела, као што су Регионално такмичење креативних дела на језицима 
ДВА НАЧИНА СПРОВОЪЕЊА ЈЕЗИЧКЕ ОБРАЗОВНЕ ПОЛИТИКЕ...

Камчатке, Такмичење у причању бајки на матерњим језицима итд. Овај рад је очигледан пример где су се сви актери унутар једне државе укључили у очување свог језика и културе, где је језичка политика спроведена одозго-на-доле, јер су сви пројекти спроведени од стране власти али на начин где су сагледане потребе становништва и где су и грађани имали прилике да активно учествују.

Економски просперитет, недостатак радне снаге у одређеним земљама и повећани број азиланата сигурно у некој мери остављају траг на етничку као и на лингвистичку сцену многих земаља. Управо су те промене довеле до повећаног интересовања за језичком политиком, наводи се у раду O’Рурка и Кастиља (2009) Top-down or Bottom-up? Language Policies in Public Service Interpreting in The Republic of Ireland, Scotland and Spain, где се истражују језичке политике спроведе одозго-на-доле од стране власти и разних институција, као и језичка политика спроведена одоздо-на-горе, која представља отпор, протест језичким политикама, а такође пружа и алтернативна решења. У раду се пре свега наводи да се језичке образовне политике не налазе у вакуму и да социополитичке и социоекономске промене у друштву имају снажан утицај на њих. Аутори објашњавају да је дошло до појављивања нових лингвистичких промена услед повећаног броја миграција у три земље наведене у наслову рада (Ирска, Шкотска и Шпанија). У прилог томе наводе извештај Европске Уније из 2007. године према коме додатни број језика који се појавио у Уједињеном Краљевству износи 288, у Шпанији 198 и Ирској 158. Након приказа тренутног стања језичких образовних политика у свакој од земаља, у раду су представљени документи у прилог спровођењу језичке политике одоздо-на-горе настали као резултат експанзије језичких иницијатива за промену лингвистичке реалности у свакој од земаља.

Када се ради о језичким образовним политикама у Србији, ауторка Дурбаба (2014) наводи да не може а да не примети да се одлуке везане за сегменте школске и високошколске наставе страних језика најчешће доносе уз потпуно игнорисање научне 
јавности и резултата научних истраживања, а веома често и у потпуној супротности са њима. Ауторка даље истиче да:

Ова жалосна чињеница, која код инволвираних истраживача неминовно изазива свест о социјалној безначајности и неуважавању њихових сазнања и ставова који се на основу тих сазнања обликују, вероватно, између осталог, говори и о природи политичког система и/или традицији политичког деловања. (...) Мишљења смо да озбиљно бављење политиком, ипак, имплицира и упућеност у све аспекте социјалне стварности, те да компликоване историјске, политичке, економске и друге прилике у последњих двадесетак година не могу бити изговор за занемаривање једне тако „ефемерне“ области као што је образовање нити за одсуство дугорочне визије његовог стратешког развоја. (Дурбаба 2014: 52)

Ипак, како ауторка објашњава, последњих десетак година дошло је до промена у школском и високошколском систему, за које се може претпоставити да представљају израз измењене образовне политике, као и да се најављују измене у области образовања у наредном периоду. Као позитивнеаспекте развоја језичке образовне политике ауторка наводи: 1) увођење другог страног језика као обавезног изборног предмета; 2) увођење раног учења првог страног језика, и то од 1. разреда основне школе; 3) проширивање палете школских страних језика увођењем италијанског, шпанског и кинеског; 4) повећање могућности за ванинституционално учење страних језика; 5) јачање мобилности ученика и наставника; 6) разноврснија понуда наставног материјала; 7) увођење билингвалних програма и других пилот-пројеката; 8) интензивирање научних истраживања из области глотодидактике; 9) развој научног подмлатка и 10) организовање наставне праксе за студенте на основним и мастер студијама. 
ДВА НАЧИНА СПРОВОЪЕЊА ЈЕЗИЧКЕ ОБРАЗОВНЕ ПОЛИТИКЕ...

\section{4. Приказ једне студије случаја}

Идеја за тему овог рада је настала као резултат рада у улози наставника енглеског језика на Пољопривредном факултету у Крушевцу. То представља моје прво радно искуство на високошколској установи, и прва година је била пуна изазова, због сусретања студената са језиком струке, тј. енглеским из области пољопривреде, што је уједно нешто са чиме сам се и сама тада сусрела први пут. Из тог разлога сам сматрала да је неопходно у оквиру овог рада описати властито лично искуство као наставника страног језика на нематичном факултету, у циљу пружања детаљног и јасног увида у начин спровођења језичке образовне политике одоздо-на-горе на Пољопривредном факултету у Крушевцу Универзитета у Нишу.

Факултет има три студијска програма и то су: воћарство и виноградарство, сточарство и ратарство и повртарство. Енглески језик је обавезан предмет за сва три студијска програма и изучава се на првој години основних академских студија у првом, односно зимском семестру. Предмет носи 4 ЕСПБ, а у спецификацији предмета за књигу предмета као циљ се наводи „Стицање знања код студената из енглеског језика и њихово оспособљавање да користе литературу на енглеском језику, усвајање способности читања на енглеском језику, усвајање комуникативних способности на енглеском језику, као и употреба стручних термина из области пољопривреде на енглеском језику“. Пре свега морам напоменути да је факултет основан у мају 2017. године, тако да сам први професор енглеског језика на тој установи, што значи да није било плана и програма који сам преузела од претходника, већ сам имала могућност да га креирам сама. Након разговора са професорима који предају енглески језик на нематичним факултетима у нашој земљи, стекла сам утисак да се, у већини случајева, настава углавном своди на читање и превођење текстова, као и на израду студентских презентација или писање семинарских радова. Прве године сам и ја тако радила, 
желећи да својим студентима пружим исти програм који имају студенти на осталим факултетима, али на крају академске године сам схватила да, сем тога што су студенти научили пар нових термина из области пољопривреде, нисам са њима остварила значајније резултате када се ради о учењу енглеског језика. Из тог разлога сам одлучила да променим план и програм за наредну академску годину, ставивши на прво место потребе студената а не начин рада на другим факултетима.

У организацији наставе на нематичним факултетима углавном сеполази од претпоставке даје највећи бројстудената усвојио енглески језик током основног и средњег образовања, па се из тог разлога сматра да без великих тешкоћа могу да наставе са учењем језика (Силашки и Ђуровић 2012: 608), што је уједно била и моја претпоставка. Међутим, стварност је много другачија, првенствено због тога што студенти долазе из различитих средњих школа и то представља велике изазове у организацији наставе, али такође утиче и на циљеве наставе енглеског језика. Након анализе студентских колоквијума, презентација, домаћих задатака, као и активности на вежбама и предавањима, утврђено је које језичке вештине представљају потешкоћу као и које су лакше за савладати. Приметно је да студентима представља велики проблем да искажу своје мишљење или одраде неку другу говорну активност на енглеском језику пред осталима, из страха од прављења грешке као и од реакције осталих студената на њихову грешку. Вежбе из енглеског језика се одржавају у групама од по 20 студената, на којима се примећује знатно веће учешће студената када се раде активности посвећене развијању говорних компетенција, док су предавања заједничка за све студијске програме, и тада се бележи слабије учешће студената. Одређен ниво нелагодности код студената се примећује и при излагању студентских презентација, где студенти у пару или мањим групама излажу своје презентације на неку од понуђених тема из области пољопривреде. Поред говорних вежби, одређени број студената има мањих потешкоћа и са применом појединих граматичких конструкција, углавном су то пасив 
ДВА НАЧИНА СПРОВОЪЕЊА ЈЕЗИЧКЕ ОБРАЗОВНЕ ПОЛИТИКЕ...

и кондиционали, што сам могла да приметим при решавању задатака писања, као и путем усменог изражавања студената. Слушање и читање су две вештине за које сам приметила да студентима не стварају веће потешкоће.

Своја запажања сам изнела декану факултета на коме радим, као и продекану за наставу, и желела бих посебно да истакнем њихову спремност да ми потпуно изађу у сусрет када се ради о мењању плана и програма након само годину дана рада. Од велике помоћи су ми биле и остале колеге који предају стручне предмете, јер су ми дали сав релевантан материјал који користе у настави, тако да су припремљене лекције које студенти касније обрађују и на другим предметима, у смислу коришћења стручних садржаја, уз то учећи и енглески језик, јер сматрам да је од кључне важности да се у наставу енглеског језика струке уведу аутентични наставни материјали, који нису креирани само у сврху усвајања страног језика. Када се ради о начину извођења наставе, настојим да створим атмосферу у којој студенти без устезања могу да се укључе у активности, где их неће савладати страх од прављења грешке, и где неће доживети енглески језик као још један предмет који само треба положити. Као што сам већ поменула у оквиру овог поглавља, на почетку прве године рада на Пољопривредном факултету сам кренула од претпоставке да је већина студената усвојила енглески језик током основног и средњег образовања, те сам сматрала да ће без већих проблема пратити наставу, али ситуација је била далеко другачија. Зато сада на почетку сваке академске године студенти на првом предавању одраде улазни тест који садржи од двадесет до тридесет питања кроз која се може утврдити ниво знања енглеског језика и на основу тога се даље припремају материјали за предавања и вежбе.

Да ли ће настава страног језика обухватати садржаје везане за одређену дисциплину или ће се фокусирати на опште ствари, зависи од факултета. Настава језика струке разликује се од наставе општег језика и по садржајима и по методологији. Када је реч о факултету на коме радим, без икаквих недоумица је одлучено да то буде језик струке, пре 
свега како би се студенти лакше укључили у академске токове, али и у сврху развијања независности, когнитивних вештина и моћи критичког размишљања, јер се настава енглеског језика на Пољопривредном факултету у Крушевцу осмишљава на основу утврђених потреба студената и захтева области којом се они баве.

Пример наведене студије случаја је јасан показатељ да језичку образовну политику не треба увек спроводити само по принципу одозго-на-доле. Како и сам назив каже, јасно је да се таква врста језичке образовне политике спроводи по хијерархијском принципу деловања, тј. надлежне институције препоручују план и програм по коме ће се радити. Битно је нагласити да циљ ове студије случаја није да представи такву језичку политику као лошу. На сопственом примеру сам се уверила да је немогуће придржавати се искључиво прописаног плана и програма, посебно када се ради о настави језика на високошколској установи; ученици долазе из различитих средњих школа, не поседују сви исти ниво знања страног језика, а деси се и да неки од њих на претходним нивоима образовања нису учили енглески као страни језик, већ неки други језик. У опису теоријске наставе из предмета Енглески језик на Пољопривредном факултету у Крушевцу стоји „Граматика (множина и род именица, заменице, прилози, предлози, времена и слагање времена, бројеви, пасивне конструкције); Морфолошки процеси (деривација; лексичка анализа текста); Обрада стручне терминологије; Синтаксичка и семантичка анализа; Писање сажетака и презентирање кључних идеја из обрађеног текста", али када се узму у обзир време предодређено за наставу страног језика као и ниво знања студената, али и њихове потребе, долази се до закључка да је веома тешко постићи све за само један семестар, колико је издвојено за наставу страног језика на Пољопривредном факултету.

Језичка политика „одоздо-на-горе“ користи сличне механизме као она „одозго-на-доле“, али при томе не примењује утемељене друштвене хијерархије и присуство менаџера који своје одлуке заснивају на ауторитету 
ДВА НАЧИНА СПРОВОЪЕЊА ЈЕЗИЧКЕ ОБРАЗОВНЕ ПОЛИТИКЕ...

институција, већ на хетерархијском устројству које условљава и конструише партнерски однос, оснаживање појединаца, умрежавање, тимски рад, све то у специфичном контексту који изнедрава нова значења. (Филиповић 2018:19)

Управо у томе лежи извор креирања плана и програма за студенте када се ради о настави енглеског језика, у партнерском односу, тимском раду, оснаживању. Материјали за предавања и вежбе се припремају у складу са потребама студената, у циљу постизања што бољих резултата за што краћи временски период.

\section{5. Закључак}

Након теоријских објашњења, као и практичних примера спровођења језичких образовних политика, стиче се утисак да када се ради ојезичким политикама одозго-на-долепостоје мане и пропусти у разним земљама у свету, не само код нас у Србији. Циљ овог рада није био да прикаже који начин спровођења језичких образовних политика је бољи, већ да пружи увид у начине њиховог функционисања, али након детаљне анализе литературе коришћене за израду овог рада, немогуће је а не приметити да постоји потреба за преиспитивањем ставова и креирањем иницијатива за ефикасније спровођење језичких политика одоздо-на-горе. Верујем да је у те сврхе неопходно укључити и научне истраживаче, наставнике јер су управо они у директном контакту са ученицима на свим образовним нивоима и најбоље могу да увиде шта је то што недостаје и треба променити, јер би језици у образовном систему требало да буду једна од важнијих тема образовне политике сваке земље. Зато треба приступити систематској анализи образовних система како би креирали планове и програме који ће донети предности и појединцима али и друштву једне земље.

С обзиром нато да се енглески језик „усталио“каоакадемска lingua franca, студенти из земаља ван енглеског говорног подручја ће се у једном тренутку суочити са енглеским језиком у току својих студија (Гредол 2006). Након детаљне анализе 
радова на тему језичке политике и планирања и језичке образовне политике, у оквиру којих је, у некима од њих, било речи и о настави страних језика на нематичним факултетима у Србији, немогуће је а не закључити да факултети у нашој земљи очигледно схватају колико је енглески језик битан у академској настави, али мишљења сам да је настава енглеског језика на нематичним факултетима у Србији отежана из више разлога. Пре свега, време које је опредељено за наставу страног језика на факултетима је кратко, страни језици се на нематичним факултетима изучавају углавном два или четири семестра, а на неким факултетима чак само и један семестар. Затим, ту су и огромне разлике међу студентима када се ради о нивоу знања енглеског језика, јер студенти долазе из разних средњих школа, те је немогуће очекивати да сви поседују исти или приближан ниво знања. На крају бих навела и да се наставници налазе пред бројним изазовима када је реч о настави енглеског као језика струке зато што током школовања нису обучавани за тај вид наставе, тако да настава језика струке пре свега изискује велику припрему наставника.

\section{ЛИТЕРАТУРА}

Бугарски 1992: R. Bugarski, Language in Yugoslavia: Situation, policy and planning. In: R. Bugarski, C. Hawkesworth (eds.), Language planning in Yugoslavia, Bloomington: Slavica Publishers, 9-26.

Вергер 2012: A. Verger, Global education policy and international development: An introductory framework. In: A. Verger, M. Movelli, H. K. Altinkyelken (eds.), Global education policy and international development: New agendas, issues and policies, London: Continuum, 3-31. Вучо 2018: Ј. Вучо, Језик и језици образовања. У: Ј. Филиповић, Ј. Вучо (ур.), Језици образовања, Београд: Филолошки факултет, 33-55. Гредол 2006: D. Graddol, English Next. British Council.

Дурбаба 2014: О. Дурбаба, Настава страних језика у Србији и аспекти језичког планирања на нивоу локалне заједнище: приказ једне студије случаја. У: Ј. Филиповић, О. Дурбаба (ур.), Језици у образовању и језичке образовне политике, Београд: Филолошки факултет, 51-73. 
Момчиловић 2012: Н. Момчиловић, Европска вишејезичност и улога енглеског језика. У: Б. Димитријевић (ур.), Филологија и универзитет, Ниш: Филозофски факултет, 617-630.

Нитфулини 2001: B. Nitfulini, The bottom up approach and top down approaches to language learning. Online, [https://www.academia. edu/32335689/]

O’Рурк и Кастиљо 2009: B. O'Rourke, D. Castillo, Top-down or bottomup? Language policies in public service interpreting in the Republic of Ireland, Scotland and Spain. Edinburgh: Center for Translation and Interpreting Studies, Heriot-Watt University.

Савица и Ђурић 2006: Т. Савица, Ж. Ђурић, Шта вири испод дечерме: Осврт на збирку задатака из српског језика. Наслеђе, 3(5), 179189.

Силашки и Ђуровић 2012: Н. Силашки, Т. Ђуровић, Енглески језик као предуслов за укључење економиста у међународне научне и стручне токове. У: Б. Димитријевић (ур.), Филологија и универзитет, Ниш: Филозофски факултет, 606-616.

Сполски 2004: B. Spolsky, Language Policy. Cambridge: Cambridge University Press.

Уједињене Нације 2016: United Nations, Language Initiatives from up to bottom and bottom up. New York: UN Department of Economic and Social Affairs, Division for Social Policy and Development, Secretariat of the Permanent Forum on Indigenous Issues, International Expert Group Meeting.

Филиповић 2014: J. Филиповић, Теоријски концепти и специфичности језичке образовне политике. У: Ј. Филиповић, О. Дурбаба (ур.), Језищи у образовању и језичке образовне политике, Београд: Филолошки факултет, 17-35.

Филиповић 2017: J. Filipović, Jezik, standardizacija, standardnojezička kultura i jezička politika i planiranje. Glasnik odjeljenja društvenih nauka, 23, 217-231.

Филиповић 2018: J. Филиповић, Језичка политика и планирање и језичко предводништво: образовање за 21. век. У: Ј. Филиповић, J. Вучо (ур.), Језици образовања, Београд: Филилошки факултет, 15-33.

Хауген 1959: E. Haugen, Planning for a Standard Language in Modern Norway. Anthropological Linguistics, 1(3), 8-21.

Хелд 2001: D. Held, Globalization. In: J. Krieger, (ed.) The Oxford Companion to Politics of the World, Oxford: Oxford University Press, Online. 


\title{
Katarina Milosavljević
}

\section{TWO WAYS OF IMPLEMENTING LANGUAGE EDUCATION POLICY: TOP-DOWN AND BOTTOM-UP; A REVIEW OF ONE CASE STUDY}

\begin{abstract}
Summary
The aim of this paper is to give an insight into the concepts of language policy and planning as well as language education policy, through a detailed review of literature, because it is language education policy that deals with languages in formal education systems. The English language takes an important place in university teaching, most literature as well as publications from the SCI (Science Citation Index) list are written in English, and knowledge of that foreign language is considered an important qualification that academic citizens should have, since it gives them the opportunity to get involved in international flows. For that reason, this paper presents a case study of the implementation of language education policy at the Faculty of Agriculture in Krusevac, University of Nis. It is important to emphasize that the aim of the paper is not to show which way of implementing language education policies is better, but to provide insight into the ways they function.
\end{abstract}

Key words: language education policy, language policy and planning, foreign language teaching, English language, higher education, faculties. 